\title{
Diversity of Rodent Species and Its Potency as the Vector for Transmitting Rodent Borne Parasitic Disease in Households
}

\author{
Nur 'Aini Herawati ${ }^{1 *}$ and Sudarmaji ${ }^{2}$ \\ ${ }^{1}$ Indonesian Legume and Tuber Crops Research Institute, J1. Raya Kendalpayak No. 66, Segaran, \\ Kendalpayak, Kec. Pakisaji, Malang - East Java, 65162 \\ ${ }^{2}$ Assessment Institute for Agricultural Technology, Jl. Stadion Maguwoharjo No. 22, Wedomartani, \\ Ngemplak, Sleman, Yogyakarta
}

\begin{abstract}
Rodent species have been known as the major pest in the agricultural sector leading to economic losses. They are also identified as the vector for several rodent-borne zoonotic diseases. However, a specific study on observing their diversity in households closed to lowland irrigated agroecosystems that correspond to disease distribution's role is limited. To address this issue, a field study was performed during the 2019-2020 cropping season in two sites (Yogyakarta and West Java) which were categorized as the rice production centers. Trapping was conducted consecutively for 13-30 days using 65-75 snap traps. Roasted coconut and salty fish were used to attract rodents. In West Java, 3 rodent species (Rattus argentiventer, Rattus tanezumi, Bandicota indica) and insectivore small mammal (Suncus murinus) were discovered from 1,950 trap nights. Meanwhile, the setting of 900 trap nights in Yogyakarta indicated less diverse rodents with only one species (Rattus tanezumi) and the same insectivore discovered. All captured animals were dissected and observed for the endoparasites. We obtained two potent species of parasites (Taenia taeniaeformis and Capillaria hepatica), which can be transmitted by rodents to the local people if they do not apply a proper health practice.
\end{abstract}

\section{Introduction}

Rodents constitute the largest group of mammals comprising 2,000-2,700 species distributed worldwide. Around 40-42\% of all mammals are categorized as the member of this group [13]. The majority of rodent species are small in body size with strong adaptation skills. They have continuously growing incisors, which leads to the frequent destructive habit of gnawing some objects [4] [3]. Additionally, this group possesses a high reproduction rate, though there are variations among species in terms of their litter size, sexual maturity at first, and the number of litters per year [5].

* Corresponding author: nherawati.yuwono@gmail.com 
Previous studies highlight that rodent species hold such benefits through ecological, scientific, social, and/or economic significances. They influence plant progression by playing an important role in distributing seeds, spores, and reprocess nutrients [6]. According to another study, these animals represent valuable species for medical and research purposes. Moreover, rodents offer meat as a protein supply for people in some areas and serve as significant prey for their predators [7]. However, rodents are considered economic and natural pests, even though accounting for about $5 \%$ of them $[8,7]$. They considerably change crop production and income of farmers in both developed and developing countries [9-11]. According to another study [12], different rodent species cause significant damage in specific food crops. In Asia, rodents have been known to be the major pest in the rice agricultural system due to the destruction of both pre-and post-harvest products, with annual losses ranging from 5 to $10 \%$ [13-14]. Moreover, damage can be remarkably critical when rodent outbreaks occur, with acute losses often greater than $30 \%$ [15].

The other negative impact of rodent existence is its significant role as carriers or reservoirs of zoonotic microbes and parasites [16-19]. They establish a prospective threat to domestic animals, including human beings. As wild animals, rodents can shelter several helminth parasites, which can be transmitted to humans and other vertebrates [20]. Therefore, they facilitate the distribution of these helminth parasites leading to zoonosis [21-22]. This [23] underlines that as their population increases, so will the zoonotic diseases in the human population.

According to a related study [24], rodents directly transmitted more than 20 diseases to humans through blood-sucking parasites such as fleas, ticks, and mites. Other studies on parasites of rodents worldwide documented a very rich biodiversity of endoparasites and ectoparasites [22], [25-28]. In Indonesia, three genera of rodents (Bandicota, Mus, and Rattus) have been identified as agricultural pests and vectors for zoonosis [29-38], [18], [3940]. Also, Similar studies found several endoparasites in the digestive system of the rice field rat (Rattus argentiventer). One of them is categorized as a cestode inhabiting the liver, which involves humans and rodents as their definitive host [41]. A continuous study in two provinces has revealed the presence of two helminth parasites in the livers of rodents and other small mammals captured in lowland rice irrigated areas and villages. In comparison to the rodent caught from the village habitat, the prevalence of infection here is higher [42].

The strong relationship between rodents, humans, and livestock and their contact with invertebrates (blood-sucking arthropods, beetles, cockroaches, and others) allows the spreading of parasites. To evaluate their potency in distributing zoonotic parasitic-borne diseases, the current study documents rodent diversity as parasite hosts in a determined area.

\section{Materials and Methods}

This study was conducted in two provinces between December 2019 and July 2020. Two villages were selected (Jayakerta and Mulyasari) in West Java and Yogyakarta (Moyudan and Jogorejo) as the trapping sites, respectively. These villages were close to a large area of lowland irrigated rice ecosystem, and the majority of the farmers in these provinces implemented conventional and common rice farming practices. Furthermore, most farming works were performed manually without reliance on a powerful machine. They also have a traditional practice of using a plastic bag to store harvested rice in their house for daily consumption. 

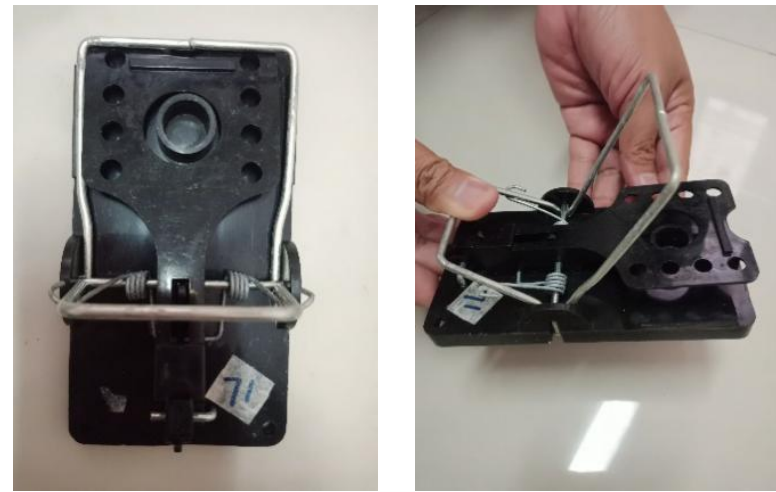

Fig. 1. Dimension of snap traps used for trapping the animals from West Java and Yogyakarta with a small wheel on the top as the bait container

Trapping was conducted to catch the rodents as the samples of this study, and snap traps were used as the tool for catching the animals. The snap trap was made from metal with dimensions of $7.5 \times 13.5 \mathrm{~cm}$, including a bait container, interconnected to a key holder (Figure 1). In these two trapping sites, 65-70 traps were set for daily trapping for 13-30 days consecutively, which equated to 1,950 and 900 trap nights, respectively. In the late afternoon of the previous day, all traps were set close to the rodents' habitat (Figure 2). To attract the animals, a daily fresh bait of salty fish and roasted coconut was applied. These traps were monitored the next morning to observe for captured animals and to replace the bait with new ones [42]. Subsequently, all captured animals were then identified morphologically [1], sexed, and recorded for the biological attributes (body weight, tail length, head-body length, mammary formulae, foot, and ear length) before dissection (Figure 3).
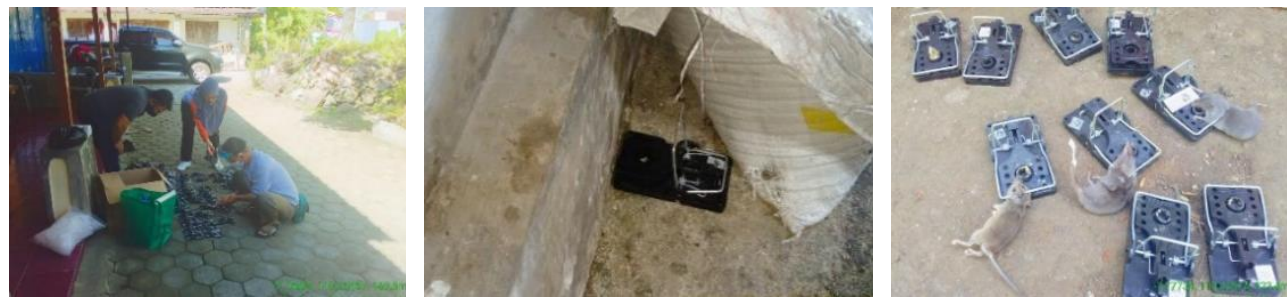

Fig. 2. Preparation of trapping by labeling and providing the fresh bait (salty fish and roasted coconut) on the runway of the animals
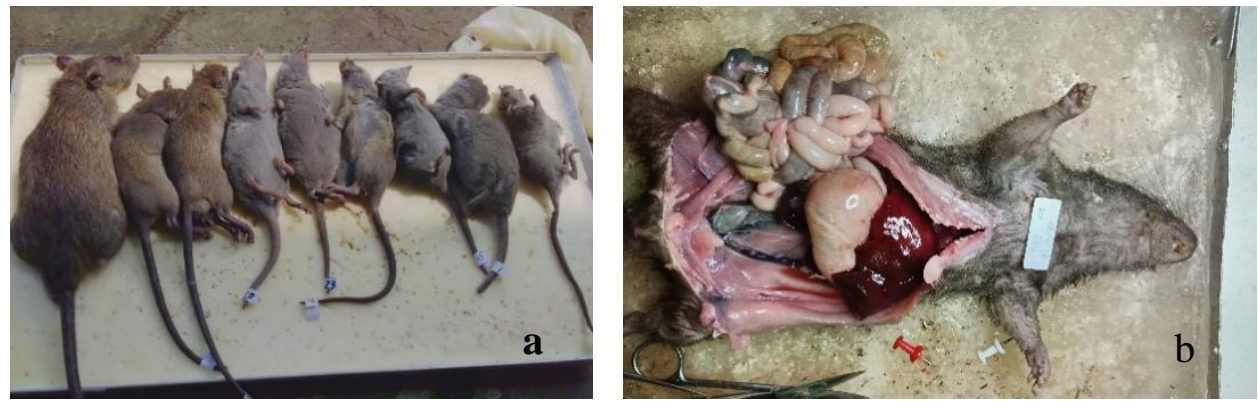

Fig. 3. Trapped rodents and insectivores from daily trapping in West Java and Yogyakarta (a) and healthy $R$. tanezumi (b)

Animals were placed on a pin wax dissecting board and fixed with pins on the board. The animals and dissecting kit were sprayed with $70 \%$ ethanol. When some parts of the animals' 
bodies disappeared due to predation, careful examination of their morphological characters was needed for proper identification [42]. Furthermore, the belly skin was lifted and incisions were made from the belly to the neck. Then, the diaphragm was sliced and the mesenteric tissue was lifted to observe every single internal organ for the parasite infection. During the dissecting, the liver was visually inspected for helminth parasites and all parasites found were recorded in the datasheet and identified for single or multiple infections. The identification of helminths was based on the description and taxonomic keys of the parasites [42, 43, 44].

\section{Results}

The diversity of rodent species was much higher in West Java when compared to the animals caught from Yogyakarta. Three species of rodent ( $R$. argentiventer, $R$. tanezumi, and $B$. indica) and one small mammal categorized as insectivore (S. murinus) were discovered. The proportion of $R$. argentiventer and $R$. tanezumi in the total of animals caught $(\mathrm{N}=130)$ were almost identical (20.8: 22.3). Meanwhile, the largest (45.4) and the smallest fraction (11.5) of the total species were obtained for $S$. murinus and $B$. indica, respectively. The sex ratio of the animals caught was almost the same with a difference of less than 5\%. Animals trapped from Yogyakarta consisted of one species of rodent ( $R$. tanezumi) only and insectivore $(S$. murinus), the same species as we retrieved from West Java (Table 1). However the sex ratio for the rodent $(R$. tanezumi $)$ was almost the same $(28.8 ; 30.4)$ in Yogyakarta, but this situation was not confirmed for the insectivore (15.2: 25.6). Regarding their basic requirements, it seems that these animals shared the habitat and food for their life. Although these rodents performed in distinct spaces, i.e. arboreal for $R$. tanezumi and terrestrial for both $R$. argentiventer and $B$. indica, they share similar food for daily consumption. Moreover, due to their predator status for small insects, which can be obtained in surrounding rice stores in farmers' houses, $S$. murinus dwelled in the same space.

Table 1. Composition of rodent and other small mammal species caught from West Java and Yogyakarta using snap traps in Yogyakarta, December 2019-July 2020

\begin{tabular}{lllll}
\hline \multirow{2}{*}{ Sexes } & \multicolumn{4}{c}{ \% species of total animal } \\
\cline { 2 - 5 } & $R$. argentiventer & $R$. tanezumi & B. indica & S. murinus \\
\hline West Java & $14(10.8)$ & $14(10.8)$ & $9(6.9)$ & $32(24.6)$ \\
\hline Males (N) & $13(10)$ & $15(11.5)$ & $6(4.6)$ & $27(20.8)$ \\
Females (N) & $\mathbf{2 7}(\mathbf{2 0 . 8})$ & $\mathbf{2 9}(\mathbf{2 2 . 3 )}$ & $\mathbf{1 5}(\mathbf{1 1 . 5})$ & $\mathbf{5 9}(\mathbf{4 5 . 4 )}$ \\
$\begin{array}{l}\text { Total } \\
\text { Yogyakarta }\end{array}$ & 0 & $36(28.8)$ & 0 & $19(15.2)$ \\
Males & 0 & $38(30.4)$ & 0 & $32(25.6)$ \\
Females & $\mathbf{0}$ & $\mathbf{7 4}$ & $\mathbf{0}$ & $\mathbf{5 1}$
\end{tabular}

Table 2 shows the prevalence of infection of helminth parasites in several rodents and insectivores. All three rodent species were found to be spontaneously infected with one or more species of helminth parasite. Out of the 130 animals examined, the rate of infection was highest in $B$. indica (33.3\%), followed by $R$. argentiventer $(18.5 \%)$, R. tanezumi $(13.8 \%)$, and $S$. murinus $(5.1 \%)$ with an overall infection rate of $13.1 \%$. Two species of helminth Taenia taeniaeformis and Capillaria hepatica were discovered in the liver with $R$. argentiventer having concurrent infection of $C$. hepatica and T. taeniaeformis. Based on the gross morphology of the liver during the necropsy, lesions consisting of uneven whitish 
cystic areas or random stripes were discovered to be dispersed on the liver surface. The following observation revealed that these rats were infected with $C$. hepatica.

Table 2. Prevalence of parasites in different rodent species trapped by using snap traps in West Java, December 2019-July 2020

\begin{tabular}{|c|c|c|c|c|c|c|c|}
\hline Species & $\begin{array}{l}\sum \text { exa } \\
\text { mined }\end{array}$ & $\begin{array}{l}\text { Numb } \\
\text { er } \\
\text { Infect } \\
\text { ed }\end{array}$ & $\begin{array}{l}\% \\
\text { Infect } \\
\text { ed }\end{array}$ & $\begin{array}{l}\text { Parasites } \\
\text { found }\end{array}$ & $\begin{array}{l}\text { Anim } \\
\text { als } \\
\text { Infect } \\
\text { ed }\end{array}$ & $\begin{array}{l}\% \text { of } \\
\text { Infected } \\
\text { Individu } \\
\text { als }\end{array}$ & $\begin{array}{l}\% \text { of } \\
\text { Total } \\
\text { Individu } \\
\text { als }\end{array}$ \\
\hline$R$. & 27 & 5 & 18.5 & $T$. & 4 & 80 & 14.8 \\
\hline argentivnter & & & & $\begin{array}{l}\text { taeniaeformis } \\
\text { C. hepatica }\end{array}$ & 1 & 20 & 3.7 \\
\hline R. tanezumi & 29 & 4 & 13.8 & $\begin{array}{l}T . \\
\text { Taeniaeformis }\end{array}$ & 4 & 100 & 13.8 \\
\hline B. indica & 15 & 5 & 33.3 & $\begin{array}{l}T . \\
\text { Taeniaeformis }\end{array}$ & 5 & 100 & 33.3 \\
\hline $\begin{array}{l}\text { S. murinus } \\
\text { Total }\end{array}$ & $\begin{array}{l}59 \\
130\end{array}$ & $\begin{array}{l}3 \\
17\end{array}$ & $\begin{array}{l}5.1 \\
\mathbf{1 3 . 1}\end{array}$ & C. hepatica & 3 & 100 & 5.1 \\
\hline
\end{tabular}

The finding was quite different as trapping from Yogyakarta revealed only one species of rodent $(R$. tanezumi) and an insectivore (S. murinus). A total number of 125 animals were examined including 74 rats ( $R$. tanezumi) and 51 insectivores (S. murinus) with concomitant infection occurring in two $R$. tanezumi by two helminth parasites (T. taeniaeformis and $C$. hepatica). However, only one insectivore was infected by the parasite ( $C$. hepatica). The overall rate of infection of $21.6 \%$ was lesser compared to those obtained from West Java trapping while the infection rate of the cestode ( $T$. taeniaeformis) was relatively higher $(35.1 \%)$ compared to C. hepatica (2\%) (Table 3).

Table 3. Prevalence of parasites in different rodent species trapped by using snap traps in Yogyakarta, December 2019-July 2020

\begin{tabular}{|c|c|c|c|c|c|c|c|}
\hline Species & $\begin{array}{l}\text { ¿examin } \\
\text { ed } \\
\text { animals }\end{array}$ & $\begin{array}{l}\text { Numb } \\
\text { er } \\
\text { infect } \\
\text { ed } \\
\text { anima } \\
\text { ls }\end{array}$ & $\begin{array}{l}\% \% \\
\text { infect } \\
\text { ed } \\
\text { anima } \\
\text { ls }\end{array}$ & $\begin{array}{l}\text { Parasites } \\
\text { found }\end{array}$ & $\begin{array}{l}\text { Anim } \\
\text { als } \\
\text { infect } \\
\text { ed }\end{array}$ & $\begin{array}{l}\% \text { of } \\
\text { infected } \\
\text { Individu } \\
\text { als }\end{array}$ & $\begin{array}{l}\% \text { of } \\
\text { Total } \\
\text { Individu } \\
\text { als }\end{array}$ \\
\hline R. tanezumi & 74 & 26 & 35.1 & $\begin{array}{l}\text { T. } \\
\text { taeniaeformis } \\
\text { C. hepatica }\end{array}$ & $\begin{array}{l}24 \\
2\end{array}$ & $\begin{array}{l}92.3 \\
7.7\end{array}$ & $\begin{array}{l}32.4 \\
2.7\end{array}$ \\
\hline $\begin{array}{l}\text { S. murinus } \\
\text { Total }\end{array}$ & $\begin{array}{l}51 \\
\mathbf{1 2 5}\end{array}$ & $\begin{array}{l}1 \\
27\end{array}$ & $\begin{array}{l}2 \\
21.6\end{array}$ & C. hepatica & 1 & 100 & 2 \\
\hline
\end{tabular}

\section{Discussion}

The trapping results showed that rodents found in West Java were more diverse compared to those in Yogyakarta. This could be because some local people in the trapping site of West Java had rice milling units. Additionally, this facility was a good dwelling for the rodents 
and even for the insectivore ( $S$. murinus). As the main post-harvest pest, $S$. murinus is a predator for small insects living in the rice milling units. During the trapping, the rice field rats ( $R$. argentiventer) and the arboreal rodents, i.e. $R$. tanezumi were often observed on the day the bait was renewed. Moreover, the trapping site in West Java represents an ideal habitat for obtaining their food, particularly rice for the rice field rat. This finding was consistent with the previous study that mentioned a strong relationship between the generative rice crop stage and rice field rats' breeding [45-46]. In addition, this situation strongly supports their breeding as rice is the main nutritional substance for triggering this cycle. During the trapping, the local farmers were also harvesting the rice crop. This situation leads to the lack of rice in the field causing the rice field rats as the main pest of this crop to move to the village around the field. However, they will be back in the field when the farmers have planted the rice crop[47].

Regarding the infection of the trapped animals' digestive system, $C$. hepatica and $T$. taeniaeformis were discovered in their liver. These two parasites were members of different groups. C. hepatica was a roundworm belonging to nematode parasites and $T$. taeniaeformis was categorized as a tapeworm and a member of cestodes [48]. Meanwhile, the infection rate of the helminth parasite $T$. taeniaeformis presented a higher percentage compared to $C$. hepatica both from West Java and Yogyakarta (Table 2 and 3). In all three rodent species, a form of whitish raised single parasitic cyst in the liver was recorded (Figure 4). The higher infection rate of this parasite in rats was probably due to the presence of cats in the surrounding trapping site. According to a related study [19], this animal carried the eggs of the parasites found on the feces. Previous studies also highlighted that T. taeniaeformis needed rodents as its intermediate host and cats as the definitive host, which passes embryonated eggs in the feces to complete its life cycle. When a suitable rodent ingests these eggs, embryonated eggs hatch in the small intestine and the embryos pass to the liver, where they develop into infective larvae in about 30 days. Transmission to the definitive host is through the ingestion of infective rodent liver. This result is coherent with the previous study, which reported that the larvae of $T$. taeniaeformis in $R$. rattus and T. indica have also been documented in countries other than India [49] [50-51]. [52] Taenia taeniaeformis (syn. Hydatigera taeniaeformis) (Cestoda: Taeniidae) is a parasite with diverse geographic dispersal and carnivores of the families Felidae, Canidae, and Mustelidae, including domestic cats and dogs, were the final hosts.

During dissection, the size of the cyst was examined to vary from 3-10 $\mathrm{mm}$ in diameter, which was coherent with the previous study describing the morphological characteristics of this parasite [19]. The researcher mentions that this larva was encapsulated in a cyst 4-12 $\mathrm{mm}$ in diameter, containing a single, live, characteristic strobilocercus larva. In addition, the larvae ranged between 12 to $20 \mathrm{~cm}$ in length. In this study, the incidence of a wide range of parasites in rodent species may be attributed to the fact that all these three rodent species were gathered regularly in the vicinity to human dwellings where interaction with the intermediate host such as grain beetle and other insects were very high. 


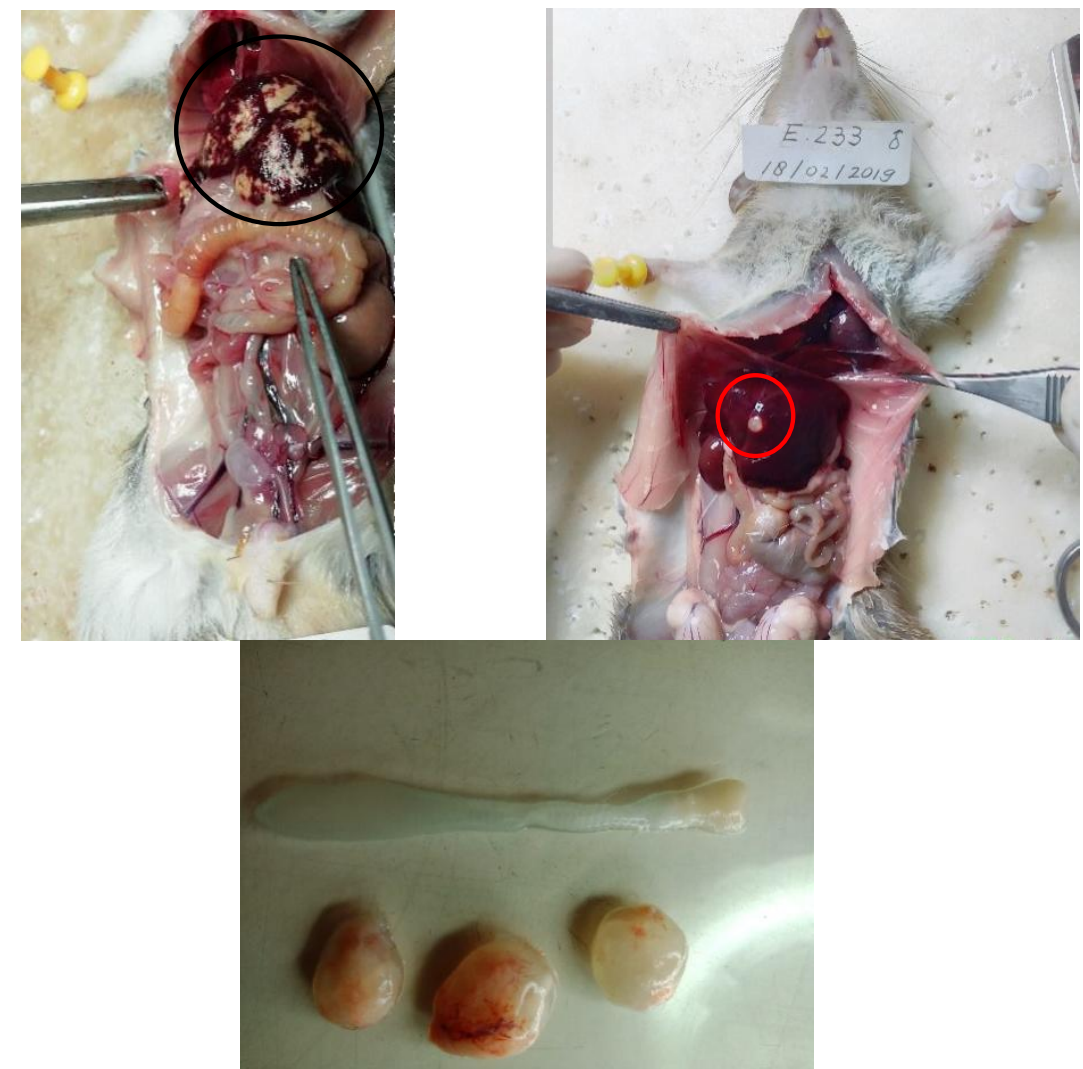

Fig.4. Infection of $C$. hepatica (left side) and T. taeniaeformis (right side) found in $R$. argentiventer. The circle indicates the liver infected by the parasite, egg deposits of $C$. hepatica (left side), and larvae of T. taeniaeformis (right side), encapsulated larvae of T. taeniaeformis (bottom photo).

The photo on the top left corner of Figure 4 represents a rice field rat infected with $C$. hepatica. On detailed gross morphological observation, pale random spots covered the liver surface. This observation was consistent with the finding previous study [53] reporting that the eggs of $C$. hepatica accumulate in the liver in the form of irregular white or yellow patches and stripes on the external surface. Another study [54] also documented that the liver is the main site of colonization of $C$. hepatica and physical damage tended to occur. The first hosts of $C$. hepatica were rodents which had relatively high infection rates leading to the spreading of $C$. hepatica globally. These parasites could be accidentally transmitted to humans by ingestion of embryonated eggs [55].

The lack of trematodes in the helminths parasites obtained in this study could be attributed to the fact that trematodes require aquatic intermediate hosts to complete their life cycle. Mollusks that live in water were the common intermediate hosts. However, the terrestrial habitat of rodents eliminated the opportunities for this kind of infection. The absence of aquatic flora was also the second possibility for the lack of trematodes found in rodents and this possibility correlates with the role of the aquatic flora as the intermediate host for the larvae of the trematodes.

Several studies also indicate numerous information on the age-prevalence effects in rodents infected with parasites such as cestodes [56] and trematodes [57]. This explains that rodents were more infected when they increased their age and engaged T. taeniaeformis when looking for their food. In another study, T. taeniaeformis prevalences depended on the age and density of voles, including seasons. There are numerous other factors, such as, cat 
population behavior and dynamics, rodent community dynamics, and meteorological or weather conditions, any of which could affect the prevalence of parasites in wild rodent populations [58]. Therefore, a comprehensive study on related subjects needs to be performed for gathering meticulous information. A sociocultural study by interviewing farmers dealing with fieldwork strongly related to the rodents movement needs to be executed. Furthermore, the interview needs to cover all information about their routine activities, ways of storing rice including their knowledge on health issues. These aspects are an important issue that could contribute to the transmission of the parasites and the promotion of healthy routines among the farmers and their environment.

\section{References}

1. K. Aplin, P.R. Brown, J. Jacob, C.J. Krebs., amd G.R. Singleton. Field methods for rodent studies in Asia and the Indo-Pacific. (2003).

2. G. Witmer. Wildl. Res. 32 (2005)

3. J.O. Wolff . Integrat. Zool. 2. (2007)

4. M. Lund. Rodent Pest and their control. 19-32 (2015)

5. G. Witmer, G. Human-Wildlife. Int. 13 (2019)

6. C. Dickman. Ecologically-based management of rodent pests. ACIAR. 113-135. (1999)

7. G. Witmer and G.R. Singleton. Rodents: habitat, pathologym and environmental impacts. 145-182 (2012)

8. I. Prakash, Rodent pest management. (1988)

9. N.C. Stenseth, L. Herwig, L., Skonhoft, A., Davis, S.A., Roger, P.P., Andereassen, H.P., Robert, G.S., Lima, M., Robert, M.M., Robert, M.H., Zhang, Z., Peter, R.B., Shi, D., and Wan, X. Front. Ecol. Environ. 1. (2003)

10. N. Singla. and Vir, R.P. Int. J. Pest. Manag. 56 (2010)

11. N. Singla and Babbar,B.K. Indian J. Ecol. 37. (2010)

12. P.R.Brown., Neil, I.H., Peter, B.B., and Grant, R.S. Agric. Eco and Environ. 120 (2007)

13. G.R..Singleton, L.A.Hinds., C. Krebs., and D. Spratt.. Rats, mice and people: rodent biology and management. Canberra. (2003)

14. J. Ashley .Food Security. 6. (2014).

15. G.R.Singleton., S. Belmain., P.R..Brown. and Hardy, B. Rodent outbreaks: ecology and impacts. IRRI. (2010)

16. E. Castillo, J. Priotto, A.M Ambrossio, M.C. Provensial, N. Pini, M.A. Morales, A.Steinmann, J.J. Plop. Int. J. Biodeteriro. Biodegrad. 52. (2003)

17. S.D. Lahmann, N. Singla., R.P Vir, B.S Sandhu, J. Singh, Rats, mice and people: rodent biology and management. Australia. 57-59. (2003)

18. S.D. Lahman, N. Singla., R.P. Vir, D.J. Prayag, and K.S. Naresh, Int. Zool. 3 (2008)

19. B.G. Meerburg. Vet. Microbiol. 142. (2009)

20. J.N. Oldham. J. Helminthol. 9. (1931)

21. L.A. Durden, R. Hu, J.H. Oliver, J.E. Cilek. Vector Ecol. 25. (2000)

22. D. Stojevic, Z. Mihaljevic, and A. Marinculic. Vet. Medicina. 49. (2004)

23. J. Bradshaw,. Environ. Health. 107. (1999)

24. N. Khatoon, F.M. Bilqees,, D. Shahwar, A.G. Rizwana,. Turkish J. Zool. 28. (2004) 
25. F.G. Claveria, J. Causapin, M.A. de Guzman, M.G. Toledo, C. Salibay. SE.J. Trop. Med. And Pub. Health. 36. (2005)

26. H. Hasegawa, Y. Ikada, A. Fujisaki, L.R. Moscovice, K.J. Petrzelkova, T. Kaur, and M.A. Huffman. J. Parasitol. 91. (2005).

27. G. Villafane, I.E., M.R. Robles, M. Busch. Helminthol, 45. (2008).

28. S. Nava, M.M. Lareschi and D. Voglino. Memorias do instituto Oswaldo Cruz. 98. (2003)

29. I.N. Ibrahim, M. Sudomo, C. Morita, S. Uemura, Y. Muramatsu, H. Uemo, H., and T. Kitamura. Japan. J. Med. Sci. Biol. 49. (1996)

30. K. Gage. Amer. J. Trop. Med. Hyg. 61. (1999).

31. I.N. Ibrahim, T. Okabayashi, Ristiyanto, E.W. Lestari, T. Yanase,U.H. Muramatsu, and C. Morita. Europ. J. Epidemiol. 15. (1999).

32. Y. Gasper. and K. Watson. Plague and yersiniasis.. Pp. 313-329. (2001)

33. M. Antolin, P. Gober, P., B. Luce. D. Biggins, W. Van Pelt, D. Seery, M. Lockhart, and M. Ball. Trans. Of the North American Wildlife and Nature Resources Conf. 67. (2002).

34. A. Plyusnina., I.N. Ibrahim, Herlina, I. Winoto, K.R. Porter, I.B.I. Gotama, A. Lundkvist, A.Vaheri, and A. Plyusnin. Scand. J. of Infect. Diseases. 36. (2004)

35. I.N. Ibrahim, and Ristiyanto. J. Ekol. Kes. 4. (2005).

36. T.T. Phan, N.T. Tam, L.T.L. Khan, N. Ogasawara, A. Nakadai, T. Iwata, T. Kamada, T and H. J. Hayashidani. Vet. Epidemiol. 9. (2005)

37. I.L.Winoto, H. Goethart, I.N. Ibrahim, I.Y. Herlina, C. Stoops, I. Susanti, W. Kania, W. Maquire, J.D., Bangs, M.J., Telford III, S.R., and C. Wongsrichanalai, SE.Asian J. Trop. Med. Publ. Health. 36. (2005).

38. I.N. Ibrahim, I. Winoto, C. Wongsrichanalai, P. Blair, and C. Stoops, C. SE.Asian J. Tropic. Med. Publ. Health. 37. (2006).

39. S. Paramasvaran, R.A. Sani, H. Kaur, M. Krishnasany, J. Jeffrey, S. Raj, S.M. Ghazali, and L.K. Hock. Trop. Biomed. 26. (2009).

40. H. Kosasih, I.N. Ibrahim, R. Wicaksono, B. Alisjahbana, Y. Hoo, L.H. Yo, L.H., U. Antonjaya, S. Widjaja, I. Winoto, M.Williams, and P.J. Blair. Vector-Borne and Zoonotic Diseases. 11. (2011).

41. N.A. Herawati and Sudarmaji. Rat, mice and people: rodent biology and management. ACIAR. Canberra. Pp. 55-56. (2003)

42. N.A. Herawati and Sudarmaji. Prevalence of infection of endoparasites and its intensity in small mammals'liver captured from irrigated rice crop area and villages, in Proceeding of the $5^{\text {th }}$ Universitas Ahmad Dahlan Publich Health Conference (UPHEC). Yogyaarta (2019)

43. EJL Soulsby Helminthes, arthropods and protozoa of domesticated animals. (Bailliere Tindall, London, 1982).

44. T.C. Cheng. The biology of animal parasites. (Toppan, 1973)

45. H. Tristiani. and M. Okimasa. Bel. J. Zool. 128. (1998)

46. H. Tristiani. and M. Okimasa. J. Zool. Lond. 259. (2003)

47. Sudarmaji dan. N. A. Herawati. Padi inovasi teknologi produksi (Buku 2). Badan Litbang Deptan. Sukamandi. Pp : 295-322. (2008).

48. C. Malsawmtluangi, and V. J. Tandon, Parasit. Dis. 33. (2009)

49. C. Namue, and C. Wongsawad. SE. J. Trop. Med. And Pub. Health. 28. (1997) 
50. C.F.Mafiana, M.B. Osho, and Sam-Wobo. J. Helmithol. 71. (1997)

51. S.M. Sadjjadi and J. Massoud. J. Vet. Parasitol. (1999).

52. I. Miyazaki. An illustrated book of helminth zoonoses. SEAMIC publication. No. 62. Tokyo. Japan. (1991). Pp. 494.

53. B.M. Gotardo, B.G. Andrade, and Z.A. Andade, Rev. Soc. Bras. Med. Trop. 33. (2000).

54. D.L. Chao, Y. Hui-Lin and W. Ying. World. J. Gastroent. 16. (2010).

55. M. Juncker-Voss, H. Prosl, H. Lussy, U. Enzenberg, H. Aver and N.J. Nowotny, Clin. Microbiol. 38. (2000).

56. J.M. Behnke, C. Barnard, J.L Hurst, P.K. Mc. Gregor and F.J. Gilbert, F. J. Helminthol. 67. (1993).

57. J.M. Duplantier, and M. J. Se'Ne, Helminthol. 74. (2000).

58. Calfet, E.F., P. Giraudoux, J.P. Que-re, and R.W. Ashford. P. J. Parasitol. 89 (2004) 